\title{
A highly efficient method for determination of some amino acids and glutathione by liquid chromatography
}

\author{
M. Czauderna, J. Kowalczyk, K.M. Niedźwiedzka and I. Wąsowska
}

\author{
The Kielanowski Institute of Animal Physiology and Nutrition, \\ Polish Academy of Sciences \\ 05-110 Jabłonna, Poland
}

(Received 30 October 2002; accepted 20 December 2002)

\begin{abstract}
High-performance liquid chromatography systems (I and II) with pre-column derivatization for separation of cyst(e)ine, selenium-cystine, homo-cystine, methionine, selenium-methionine, proline and glutathione $(\mathrm{GSH})$ in biological materials are described. Biological samples were derivatizated with $o$-phthaldialdehyde (OPA) in the presence of ethanethiol. Prior to derivatization, cyst(e)ine, methionine, GSH and proline were oxidized using improved procedures. Performic acid and sodium hypochlorite were used as the oxidizing reagents. HPLC analyses of derivatives of all oxidized compounds were carried out using a $\mathrm{C}_{18}$ column $(4 \mu \mathrm{m}, 250 \times 4.6 \mathrm{~mm}$ I.D., Nova Pak, Waters $)$ and binary gradient elution program I (HPLC system I). HPLC system I with UV monitoring (at $336 \mathrm{~nm}$ ) and fluorescence detection (excitation and emission wavelengths at $\lambda_{\mathrm{ex}} / \lambda_{\mathrm{em}}=336 / 425 \mathrm{~nm}$ ) was chosen as providing the optimum conditions for fractionation and quantification of all of the examined compounds. In comparison with the UV detection, fluorescence detection offers better sensitivity (limits of detection: 0.9-2.4 vs 0.3-0.8 ng. $\left.1^{-1}\right)$. Clear separation of cyst(e)ine, GSH, methionine and proline was obtained in about $35 \mathrm{~min}$. Separation of unoxidized GSH, cystine, seleno-cystine, methionine, seleno-methionine, homo-cystine from other free amino acids was achieved using HPLC system II with UV detection at $337 \mathrm{~nm}$ and/or fluorescence detection $\left(\lambda_{\mathrm{ex}} / \lambda_{\mathrm{em}}=336 / 425 \mathrm{~nm}\right)$. Compared with fluorescence detection, UV monitoring offers better limits of detection $\left(\mathrm{L}_{\mathrm{D}}\right)$ of cystine, seleno-cystine and homo-cystine, while worse $\mathrm{L}_{\mathrm{D}}$ for $\mathrm{GSH}$, methionine and seleno-methionine. The satisfactory purity of analytical peaks of the assayed compounds (near 100\%), and the simplicity and precision of HPLC systems I and II render these methods suitable for routine analysis of these compounds in large numbers of biological samples.
\end{abstract}

KEY WORDS: amino acid determination, cyst(e)ine, Se-cystine, homo-cystine, methionine, Se-methionine, proline, glutathione, HPLC 


\section{INTRODUCTION}

Proteins in foods contain some twenty common amino acids. All twenty amino acids are needed for protein biosynthesis, although about nine cannot be synthesized or adequately synthesized in the human body, and are referred to as essential amino acids (Lewis and Bayley, 1995; Ravindran and Bryden, 1999). In addition, some feed proteins usually contain hydroxyl-amino acids such as hydroxyl-proline or hydroxyllysine. Dietary requirements for protein and amino acids are based on demand for total amino nitrogen, essential amino acids and other important nitrogen compounds, such as neuro-transmitters and peptide hormones (Lindroth et al., 1985; Żebrowska and Buraczewski, 1998). Moreover, monitoring of sulphur- containing amino acids is important for nutritional and biochemical research, in pharmacodynamic studies of thiol drugs, or in the diagnosis of some diseases (Bald and Głowacki, 2001). In fact, cysteine is metabolically related to homo-cysteine and glutathione (GSH) (Bald et al., 2001). Homo-cysteine can be remethylated to methionine, important amino acids in protein biosynthesis, or converted to cysteine in the trans-sulphuration pathway (Chwatko and Bald, 2002). Therefore, there is ongoing interest in the improvement of chromatographic methods for determination of sulphur amino acids and GSH in biological samples for regulatory purposes and examination of amino acid profiles in foods. Traditionally, amino acids are separated by ion-exchange chromatography (IEC) with ninhydrin derivatization (Ng et al., 1991; Moller, 1993; Sarwar and Botting, 1993). However, in the last year HPLC methods have replaced IEC. Indeed, due to the use of simpler instrumentation in pre-column derivatization, small-bore HPLC columns, small particle size $(3-5 \mu \mathrm{m})$ resins, high-pressure pumps coupled with high-sensitivity detectors, HPLC methods offer reduced analysis time and improved limits of detection of about 1 pmol (Sarwar and Botting, 1993; Williams, 1994; Cohen and Michaud, 1998; Czauderna and Kowalczyk, 1998; Peter et al., 1998; Polak and Golkiewicz, 2000; Czauderna et al., 2002). The most widely used reagent for derivatization was $o$-phthaldialdehyde (OPA) in the presence of a thiol (Kutlan and Molnar-Perl, 2001; Molnar-Perl, 2001; Czauderna et al., 2002). Unfortunately, due to the lack of OPA reactivity with imino acids, instability of methionine during hydrolysis of proteins and poor fluorescence of cyst(e)ine OPA derivatives (Lindroth et al., 1985; Czauderna et al., 2002), these amino acids should be oxidized prior to derivatization (Bech-Andersen et al., 1980; Czauderna and Kowalczyk, 1998) and then separated as OPA derivatives using reversed-phase HPLC systems. Therefore, the main purpose of the current study was to develop and improve oxidation procedures and HPLC methods with OPA-pre-column derivatization for simultaneous determination of cyst(e)ine, methionine, GSH and proline in biological materials. Furthermore, attention has also been paid to omitting the oxidation steps and simultaneous quantification of OPA-derivatized GSH, homo-cystine, cystine, methionine, selenocystine and seleno-methionine in the presence of other amino acids. 


\section{MATERIAL AND METHODS}

All amino acids, glutathione (GSH) and $o$-phthaldialdehyde (OPA) were obtained from Sigma (St. Louis, MO, USA) while ethanethiol (ESH), tetrahydrofuran (THF) and sodium hypochlorite water solution $(4 \%$ available $\mathrm{Cl})$ were from Flucka. All other reagents were of analytical grade (POCh, Poland), whereas methanol was gradient HPLC grade (Becker). Water used for the preparation of mobile phases and chemical reagents was prepared using an $\mathrm{Elix}^{\mathrm{TM}}$ water purification system (Millipore). The mobile phases were filtered through a $0.45 \mu \mathrm{m}$ membrane filter (Millipore). The amino acid protein hydrolysate standard kit was obtained from Waters Corporation (AccQ·Tag ${ }^{\text {TM }}$, Part No. WATO52875, USA).

\section{Chromatographic equipment}

An alliance separation module (model 2690, Waters) with a Waters 996 photodiode array detector (DAD) and Waters 474 fluorescence detector (FD) was used for development of HPLC methods. An autosampler was thermostated at $4^{\circ} \mathrm{C}$. The OPA derivatized compounds in the effluent were simultaneously detected by DAD and FD. DAD was operated in a UV range from 195 to $390 \mathrm{~nm}$ with a measurement frequency of 1 spectrum per sec and a spectral resolution of 1.2 $\mathrm{nm}$. The OPA-derivatized amino acids and GSH were UV detected at 336 or 337 $\mathrm{nm}$, while fluorescence detection was at an excitation wavelength of $336 \mathrm{~nm}$ and an emission cut-off filter of $425 \mathrm{~nm}$. An analytical Nova Pak $\mathrm{C}_{18}$ column $(4 \mu \mathrm{m}$, $250 \times 4.6 \mathrm{~mm}$, I.D., Waters) was fitted with a pre-column of 10x6 mm I.D. (Nova Pak, Waters) containing $\mathrm{C}_{18}$ pellicular packing material $(30-40 \mu \mathrm{m})$.

\section{Analytical mobile phases and gradient elution programs}

Two gradient elution programs were used for fractionation and quantification of the assayed compounds in the examined samples. In HPLC system I the following gradient elution program I was used (Table 1). Solvent A was THF - $0.05 \mathrm{M}$ sodium acetate ( $\mathrm{pH}$ was adjusted to 6.6 with phosphoric acid) $(1: 99, \mathrm{v} / \mathrm{v})$, while solvent $\mathrm{B}$ was methanol. For analysis of unoxidized analytes, gradient elution program II was applied (Table 2). The following elution mobile phases were used: solvent $\mathrm{C}$ was THF - buffer $\mathrm{C}(1: 99, \mathrm{v} / \mathrm{v})$. Buffer $\mathrm{C}$ was prepared from $0.02 \mathrm{M} \mathrm{Na}_{2} \mathrm{HPO}_{4}$ adjusted to $\mathrm{pH} 3.5$ with $10 \%$ phosphoric acid. Solvent D was THF - buffer B (1:99, $\mathrm{v} / \mathrm{v})$. Buffer B was prepared from $0.04 \mathrm{M} \mathrm{Na}_{2} \mathrm{HPO}_{4}$ adjusted to $\mathrm{pH} 6.6$ with $10 \%$ phosphoric acid. Solvent B was methanol, while the last solvent used in this HPLC system was water (solvent E). The minimal system pressure was $20.1 \pm 0.1 \mathrm{MPa}$; the maximal pressure was 37.4 $\pm 0.2 \mathrm{MPa}$. Injection volumes were 5-30 $\mu$ l. Amino acids were identified by the retention time of processed standards injected separately 
TABLE 1

Binary gradient elution program $\mathrm{I}^{1}$ used for analysis of oxidized assayed species (pre-column OPA HPLC system I)

\begin{tabular}{ccc}
\hline Time & \multicolumn{2}{c}{ Composition $^{2}, \%$} \\
\cline { 2 - 3 } $\min$ & solvent A & solvent B (methanol) \\
\hline 0 & 85 & 15 \\
3 & 72 & 28 \\
20 & 56 & 44 \\
26 & 44 & 56 \\
34 & 20 & 80 \\
54 & 79 & 21 \\
\hline
\end{tabular}

${ }^{1}$ the initial flow-rate was $1.3 \mathrm{ml} / \mathrm{ml}$, then $1.5 \mathrm{ml} / \mathrm{min}$ from 20 to $60 \mathrm{~min}$

${ }^{2}$ all changes of solvents composition were linear

TABLE 2

Quaternary gradient elution program $\mathrm{II}^{1}$ used for analysis of OPA-derivatizated free amino acids and GSH in biological materials (pre-column OPA HPLC system II)

\begin{tabular}{ccccc}
\hline \multirow{2}{*}{$\begin{array}{c}\text { Time } \\
\text { min }\end{array}$} & \multicolumn{4}{c}{ Composition $^{2}, \%$} \\
\cline { 2 - 5 } & solvent B & solvent C & solvent D & solvent E \\
\hline 0 & 15 & 0 & 85 & 0 \\
1.8 & 15 & 0 & 85 & 0 \\
3.0 & 28 & 0 & 72 & 0 \\
19.0 & 28 & 0 & 72 & 0 \\
19.5 & 36 & 0 & 64 & 0 \\
22.0 & 36 & 0 & 64 & 0 \\
28.0 & 46 & 0 & 54 & 0 \\
30.2 & 45 & 55 & 0 & 0 \\
30.5 & 56 & 44 & 0 & 0 \\
35.5 & 57 & 43 & 0 & 0 \\
37.0 & 56 & 0 & 44 & 0 \\
42.0 & 63 & 0 & 37 & 0 \\
45.0 & 60 & 0 & 40 & 0 \\
50.0 & 80 & 0 & 0 & 20 \\
$55.0^{3}$ & 85 & 0 & 0 & 15 \\
\hline
\end{tabular}

${ }^{1}$ flow-rate: $1.8 \mathrm{ml} / \mathrm{min}$; column temperature: $37^{\circ} \mathrm{C}$

${ }^{2}$ all changes of solvent composition were linear

${ }^{3}$ after $53 \mathrm{~min}$, the column was re-equilibrated for $10 \mathrm{~min}$ in $85 \%$ solvent $\mathrm{B}$ and $15 \%$ solvent $\mathrm{C}$ at a flow-rate of $1.8 \mathrm{ml} / \mathrm{min}$

and by adding standard solution to biological samples. The limit of detection $\left(\mathrm{L}_{\mathrm{D}}\right)$ was calculated as a signal-to-noise ratio of 3 , while the limit of quantification $\left(\mathrm{L}_{\mathrm{O}}\right)$ was defined as 10 times the noise under a peak (Gratzfeld-Husgen and Schuster, 1996; Meyer, 1999). 


\section{Preparation of the borate buffer}

Boric acid, $2.474 \mathrm{~g}$, was dissolved in $80 \mathrm{ml}$ of HPLC grade water and the $\mathrm{pH}$ was adjusted to 9.8-9.9 with $5 \mathrm{M} \mathrm{KOH}$. The resulting solution was filtered through filter paper and then diluted to a volume of $100 \mathrm{ml}$ to make $0.4 \mathrm{M}$ borate buffer.

\section{Preparation of oxidizing solutions}

$\mathrm{NaClO}$ (oxidizing reagent 1): to $0.995 \mathrm{ml}$ of deionised water, $5 \mu \mathrm{l}$ of sodium hypochlorite solution ( $4 \%$ available $\mathrm{Cl}$ ) were added.

Performic acid (oxidizing reagent 2): $0.1 \mathrm{ml}$ of $40 \%$ hydrogen peroxide and $1.125 \mathrm{ml}$ of $85 \%$ formic acid were allowed to incubate at $50^{\circ} \mathrm{C}$ for $3 \mathrm{~min}$.

It is recommended to protect the oxidation reagents from light and to store refrigerated at $-79^{\circ} \mathrm{C}$ when not in use. As a guide, fresh reagent solutions should be used.

\section{Preparation of derivatizing reagent (OPA/ESH)}

Seventy $\mathrm{mg}$ of OPA were dissolved in $4.5 \mathrm{ml}$ of methanol and $0.5 \mathrm{ml}$ of the borate buffer. Next, $0.08 \mathrm{ml}$ of ESH was added and the resulting solution was mixed. The reagent solution was prepared at least $3 \mathrm{~h}$ before use. It is recommended to protect the derivatizing solution from light and to store refrigerated $\left(-18^{\circ} \mathrm{C}\right)$ when not in use. This solution was retained no longer than two weeks. The reagent strength was maintained by addition of $10 \mu 1$ of ESH every 2-3 days.

\section{Preparation and hydrolysis of biological materials}

Samples of rumen bacteria (Lachnospira multiparus 685) were frozen, freezedried and the obtained homogeneous materials $(\sim 500 \mathrm{mg})$ were hydrolysed with 50 $\mathrm{ml}$ of $6 \mathrm{M} \mathrm{HCl}$ at $104 \pm 2^{\circ} \mathrm{C}$ for $20 \mathrm{~h}$ in sealed tubes. After cooling the hydrolysates were filtered through filter paper and washed three times with water. Hydrochloric acid was removed from the filtrates in a vacuum rotary evaporator. Ten $\mathrm{ml}$ of deionized water were added to the residue and then evaporated to dryness again in vacuum to remove residues of $\mathrm{HCl}$. This evaporating procedure was repeated two times. The lyophilized residues were stored at $-18^{\circ} \mathrm{C}$ when not in use. The residue was re-dissolved in $1 \mathrm{ml}$ of the borate buffer ( $\mathrm{pH}$ 9.8-9.9). 10-40 $\mu$ l of the resulting solution were used for the OPA/ESH derivatization procedures as below.

\section{Derivatization procedure I with improved oxidation step 1}

To autosampler vial I were added 10-20 $\mu \mathrm{l}$ of an assayed sample, $0.2 \mathrm{ml}$ of oxidizing reagent $1(\mathrm{NaClO})$ and $20 \mu \mathrm{l}$ of $2 \mathrm{M} \mathrm{NaOH}$. The content was mixed and 
reacted for $24 \mathrm{~min}$ at $25^{\circ} \mathrm{C}$. At the end of the $24 \mathrm{~min}$ period, $0.45 \mathrm{ml}$ of the OPA/ ESH reagent were added to the first vial and allowed to react for 2 min. Mixture I was protected from light.

Derivatization procedure II with improved oxidation step 2

To autosampler vial II were added $10-20 \mu$ of an assayed sample and $20 \mu 1$ of oxidizing reagent 2 (performic acid). The content was mixed and reacted for $24 \mathrm{~min}$ at $40^{\circ} \mathrm{C}$. Oxidation was terminated by adding ca. $20-30 \mathrm{mg}$ of sodium pyrosulphide $\left(\mathrm{Na}_{2} \mathrm{~S}_{2} \mathrm{O}_{5}\right.$ ). After cooling (to $0-1^{\circ} \mathrm{C}$ ), the $\mathrm{pH}$ of the resulting solution was adjusted to $9-10$ by adding $0.04 \mathrm{ml} 10 \mathrm{M} \mathrm{NaOH}$. Next $0.45 \mathrm{ml}$ of the OPA/ESH reagent was added to vial II and allowed to react for $2 \mathrm{~min}$. Mixture II was protected from light.

\section{HPLC analysis}

Mixtures I and II were then combined and after mixing, 10-40 $\mu 1$ of the resulting solution were injected onto the HPLC column. The separation and quantification of OPA derivatives of oxidised compounds was performed using HPLC system I. The derivatizing procedures for standards were the same as for biological samples.

\section{Procedure for OPA derivatization of free amino acids}

To blood plasma samples $(20-50 \mu 1)$ or other physiological fluids $(30-50 \mu 1)$ (Czauderna and Kowalczyk, 1998; Czauderna et al., 2002), immediately after collection, was added $0.9 \mathrm{ml}$ of the OPA/ESH reagent and then the $\mathrm{pH}$ was adjusted to 9-10 with $10-20 \mu \mathrm{l}$ of $2 \mathrm{M} \mathrm{NaOH}$. At the end of the $2 \mathrm{~min}$ period, $10-40 \mu \mathrm{l}$ of the resulting solution were injected onto the column. The standards were processed in the same way as the biological samples. Separation of derivatized unoxidised compounds was carried out using HPLC system II.

\section{RESULTS AND DISCUSSION}

The goal of elucidating the physiological functions of sulphur, selenium amino acids, GSH (the major cellular thiol) and proline provided the impetus for the development of accurate and sensitive OPA-HPLC methods for simultaneous determination of these compounds in the presence of other amino acids. Moreover, HPLC analyses of this type are performed at research centres conducting nutritional studies. Therefore, to achieve optimal conditions for assays of biological samples, a long column $(250 \mathrm{~mm})$ packed with strongly hydrophobic silica bonded phase $\left(\mathrm{C}_{18}\right)$ with photodiode array detection should be used. 
Because proline (i.e. an imino acid) lacks OPA reactivity, it was first oxidised with sodium hypochloride in an alkaline medium (Czauderna and Kowalczyk, 1998) and then separated after pre-column OPA-derivatization. However, in order to improve the purity of the obtained oxidation products we applied a more diluted solution of $\mathrm{NaClO}$ (i.e. $0.02 \%$ available $\mathrm{Cl}$ ) than used in our previous studies (i.e. $0.3 \%$ available $\mathrm{Cl}$ ) (Czauderna and Kowalczyk, 1998). As the objective of the presented work was to develop a new HPLC method for simultaneous determination of other important compounds, we combined the improved $\mathrm{NaClO}$ oxidation of proline (step 1) with improved oxidation of cyst(e)ine, methionine and GSH with using performic acid (step 2). Next, the oxidized compounds reacted with the OPA/ESH reagent (in $\sim \mathrm{pH} 9$-10) to form derivatives possessing very high molar absorption in the long UV range (i.e. from 320 to $360 \mathrm{~nm}$ ). Indeed, these OPA-derivatives having a high quantum yield ensured high sensitivity of UV and fluorescence detection. Recent work (Czauderna and Kowalczyk, 1998; Czauderna et al., 2002) has demonstrated that OPA amino acid derivatives can be successfully quantificated by reversed-phase $\mathrm{C}_{18}$ columns using a gradient elution program and UV or fluorescence detection. Thus, for real biological samples it is necessary to optimise the gradient program, UV and fluorescence detection. Fortunately, binary gradient elution program I (Table 1) composed of sodium acetate buffer ( $\mathrm{pH}$ 6.6) in methanol was found to provide excellent baseline stability and a wide range of solvent strength. By manipulating the percentage of buffer in methanol, the new OPA- HPLC system I enabled satisfactory fractionation of derivatives of oxidized cyst(e)ine, methionine, GSH and proline in bacterial samples and in amino acid protein hydrolysate standard. All analytes were substantially retained on the Nova Pak $\mathrm{C}_{18}$ column. Satisfactory peak shapes, nearly symmetrical, were obtained with sample elution times from 5 to $36 \mathrm{~min}$. In our HPLC system I cyst(e)ine was eluted at $5.8 \pm 0.2$ and $6.6 \pm 0.2 \mathrm{~min}$, $\mathrm{GSH}$ at $20.4 \pm 0.2 \mathrm{~min}$, methionine at $24.2 \pm 0.3$ and $25.3 \pm 0.3 \mathrm{~min}$, while proline had a retention time of $33.9 \pm 0.3 \mathrm{~min}$ (Figure 1). As expected, the peaks of all assayed compounds were absent from the blank when the presented HPLC system I was used. Although fluorescence detection $\left(\lambda_{\mathrm{ex}} / \lambda_{\mathrm{em}}=336 / 425 \mathrm{~nm}\right)$ is usually applied (Lindroth et al., 1985; Czauderna and Kowalczyk, 1998; Czauderna et al., 2002), UV detection at $336 \mathrm{~nm}$ also provided adequate sensitivity when compared with the original concentration of these species in biological materials. The reliability of the proposed HPLC system I was evaluated by simultaneous use of UV-photodiode and fluorescence detection. The accuracy of HPLC system I with UV detection was documented by comparing UV spectra (from 195 to $390 \mathrm{~nm}$ ) of assayed analytes in standards and ones in examined biological materials or the amino acid protein hydrolysate standard. No co-elution of assayed compounds with unidentified species present in the examined materials was observed for UV detection in the spectral ranges of 215-245 and 300-360 $\mathrm{nm}$. Subsequently, attempts were made to compare the results as dependent on the detection mode used. As can be seen from HPLC 

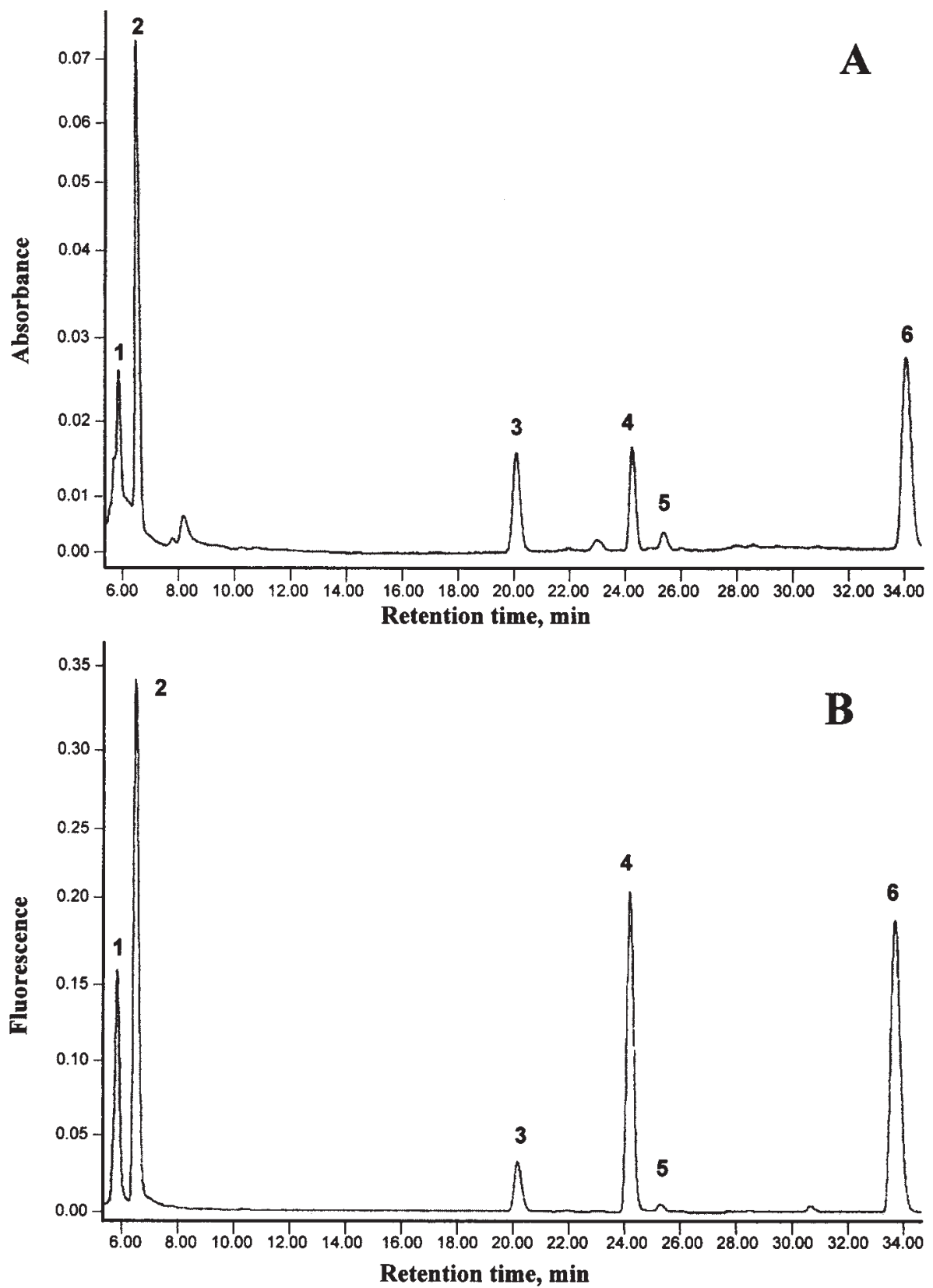

Figure 1. Part of typical HPLC chromatogram for oxidized compounds as OPA/ESH derivatives obtained by the binary gradient elution program I (the HPLC system I) with UV detection at 336 $\mathrm{nm}$ (a chromatogram A) and the fluorescence detection $\left(\lambda_{\mathrm{ex}} / \lambda_{\mathrm{em}}=336 / 425 \mathrm{~nm}\right)$ (a chromatogram B). Injection volume was $20 \mu$ l. Peaks: 1 and 2 - cyst(e)ine; 3 - glutathione (GSH); 4 and 5 - methionine; 6 - proline 
runs of processed samples, the response ratios of the photodiode detector (DAD) to the fluorescence detector were practically identical for all examined compounds in all assayed standards and biological samples. Furthermore, the same relations were obtained when another binary gradient elution program (not presented in the current study) with the same detection modes was applied. As expected, excitation at $230 \mathrm{~nm}\left(\lambda_{\mathrm{ex}} / \lambda_{\mathrm{em}}=230 / 470 \mathrm{~nm}\right)$ provided a greater response of the fluorescence detector as compared to excitation at $336 \mathrm{~nm}\left(\lambda_{\text {ex }} / \lambda_{\text {em }}=336 / 425 \mathrm{~nm}\right)$ and UV detection at $336 \mathrm{~nm}$, however, the noise and background fluctuations are larger for fluorescence detection using $230 \mathrm{~nm}$ excitation. Consequently, the limits of detection $\left(\mathrm{L}_{\mathrm{D}}\right)$ for the assayed compounds were worse and, especially for biological samples, the analytical peaks were not clearly resolved from interfering impurities (i.e. decreased precision of analyses). The results of GSH determination were particularly interesting and important (Table 3 ) because UV detection at $336 \mathrm{~nm}$ produced a greater signal than fluorescence detection applying a $336 \mathrm{~nm}$ excitation wavelength. Detailed analysis of chromatograms (Figure 1) and results summarized in Table 3 evidenced that the second cyst(e)ine peak and the first methionine peak (i.e. larger peaks) are most suitable for routine analysis.

Attempts were made to evaluate the accuracy of HPLC system I by analysing recovery ( $\mathrm{R}, \%$ ) of a known quantity of analysed compounds from bacteria (from 1 to 2 $\mathrm{mg}$ of lyophilized bacterial hydrolyzate). The obtained average recovery for assayed compounds evidenced that the examined HPLC system I provided satisfactory accuracy when UV monitoring at $336 \mathrm{~nm}$ (i.e. $96-101 \%$ ) and fluorescence detection $\left(\lambda_{\mathrm{ex}} / \lambda_{\mathrm{em}}=336 / 425 \mathrm{~nm}\right)$ (practically $100 \%$ ) were applied. Comparison of UV spectra of the examined species in standards and ones in biological samples also proved the accuracy of the presented HPLC system. Furthermore, we investigated the relationships between the UV detection wavelength $\left(\lambda_{\text {nm }}\right)$ and ratios $\left(\mathrm{R}_{\text {sample }}^{\mathrm{nm}}\right)$ of peak areas of the examined compounds in rumen bacteria and calibration standards $\left(\mathrm{R}^{\mathrm{nm}}{ }_{\text {standard }}\right.$ ) (for abbreviations see Table 3 ). As can be seen from results obtained from detection in the long UV range (300-360 nm), all average values of $\mathrm{R}^{\mathrm{nm}}$ of cyst(e)ine, GSH, methionine and proline were nearly 1 . Therefore, these compounds can be determined using long UV-wavelengths. As expected, in the examined short UV range (from 215 to $245 \mathrm{~nm}$ ) all values of relative standard deviation (RSD) were also small, as well as average values of $\mathrm{R}^{\mathrm{nm}}$ were practically equal to 1 . However, we suggest that the current HPLC system I based on longer wavelength UV detection $(300-360 \mathrm{~nm})$ is more suitable for analysis of the assayed compounds since other endogenous species, in general, possess relatively high absorbance in the short UV range $(\lambda<240 \mathrm{~nm})$. Indeed, the presented data (Table 3 ) documented that detection at the longer UV range $(300-360 \mathrm{~nm})$ provides better purity of analytical peaks (compare values of RSD and $\mathrm{R}^{\mathrm{nm}}$ for applied short and longer UV range). Moreover, the high molar absorptivity of OPA derivatives and the close proximity to the absorbance maximum at $335-336 \mathrm{~nm}$ was almost ideally suited for analysis 


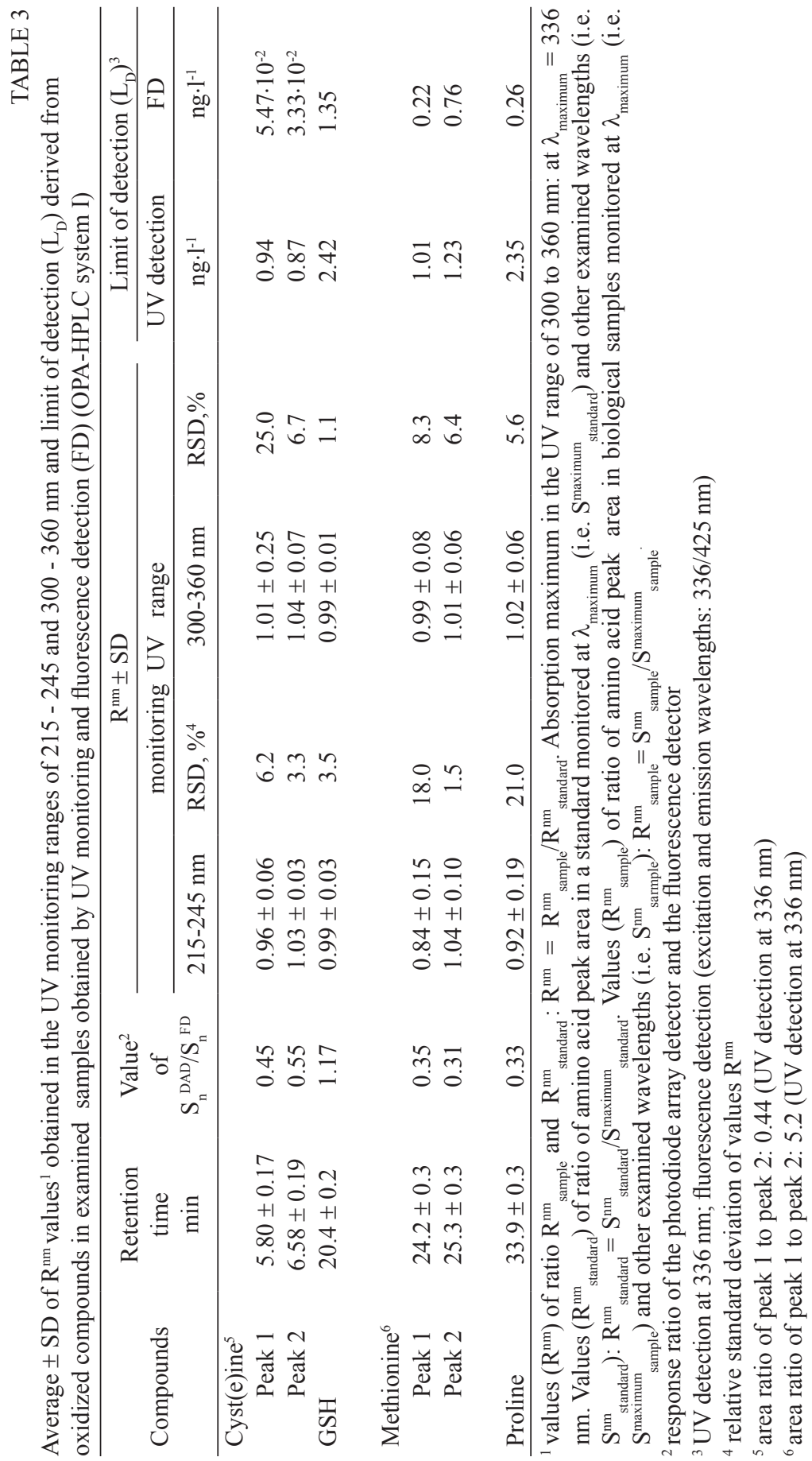


of these compounds. Consequently, all analytical peaks can be integrated using the total peak area method.

The stability of oxidized compounds was investigated in detail at $-18^{\circ} \mathrm{C}$ with respect to storage time of processed standards and biological samples. Our studies indicated that the areas of the assayed compounds were practically the same when processed samples were protected from light and stored for $1 \mathrm{~h}$ at $-18^{\circ} \mathrm{C}$. Unfortunately, the main disadvantage of oxidised cysteine derivatives is their high instability; in fact, $24 \mathrm{~h}$ of storage at $-18^{\circ} \mathrm{C}$ of derivatives of oxidized cyst(e)ine exhibited $\sim 50 \%$ degradation.

As can be seen from the limit of detection $\left(\mathrm{L}_{\mathrm{D}}\right)$ summarized in Table 3, the proposed HPLC system I with UV or fluorescence detection offers satisfactory sensitivity permitting detection and quantification of a relatively low level of these compounds compared with the original contents of free cyst(e)ine, methionine, proline and GSH in biological materials. As expected, the obtained values of $\mathrm{L}_{\mathrm{D}}$ evidenced that fluorescence detection used at $336 \mathrm{~nm}$ excitation offers the highest sensitivity for all assayed compounds.

\section{Determination of free amino acids and GSH}

In order to minimize the contribution of sample preparation, the oxidation steps were omitted. Therefore, immediately after collection the assayed samples were derivatized using OPA in the presence of ESH. The key step in OPA-derivatized free amino acid analysis is complete separation from numerous unidentified endogenous species present in biological materials. The results from previous studies (Czauderna and Kowalczyk, 1998; Czauderna et al., 2002) and the current exhaustive investigation have demonstrated that a long $\mathrm{C}_{18}$ column $(25 \mathrm{~cm}$, Nova Pak) and UV monitoring (at $337 \mathrm{~nm}$ ) or fluorescence detection $\left(\lambda_{\mathrm{ex}} / \lambda_{\mathrm{em}}=336 / 425\right.$ $\mathrm{nm}$ ) provide suitable HPLC conditions for simultaneous determination of cystine, seleno-cystine, homo-cystine, methionine and seleno-methionine in the presence of other amino acids (Figure 2). Moreover, as can be seen in Figure 2, HPLC system II also resulted in satisfactory separation of GSH from all assayed amino acids. Satisfactory chromatographic fractionation in ca 53 min of an HPLC run was achieved due to the use of quaternary gradient reversed-gradient HPLC system II with UV detection in a relatively clean UV region (i.e. $337 \mathrm{~nm}$ ) or selective fluorescence detection $\left(\lambda_{\mathrm{ex}} / \lambda_{\mathrm{em}}=336 / 425 \mathrm{~nm}\right)$. Unidentified endogenous species present in rumen bacteria, intestinal digesta, faeces, meat and milk therefore do not interfere with all assayed compounds (Czauderna et al., 2002). Obviously all examined compounds were absent from the blank when HPLC system II was used. The accuracy of the described HPLC system II was assessed by the response ratios of assayed analytes of UV and fluorescence detector for standards and biological samples. As expected, the response ratios of DAD to the fluorescence detector 

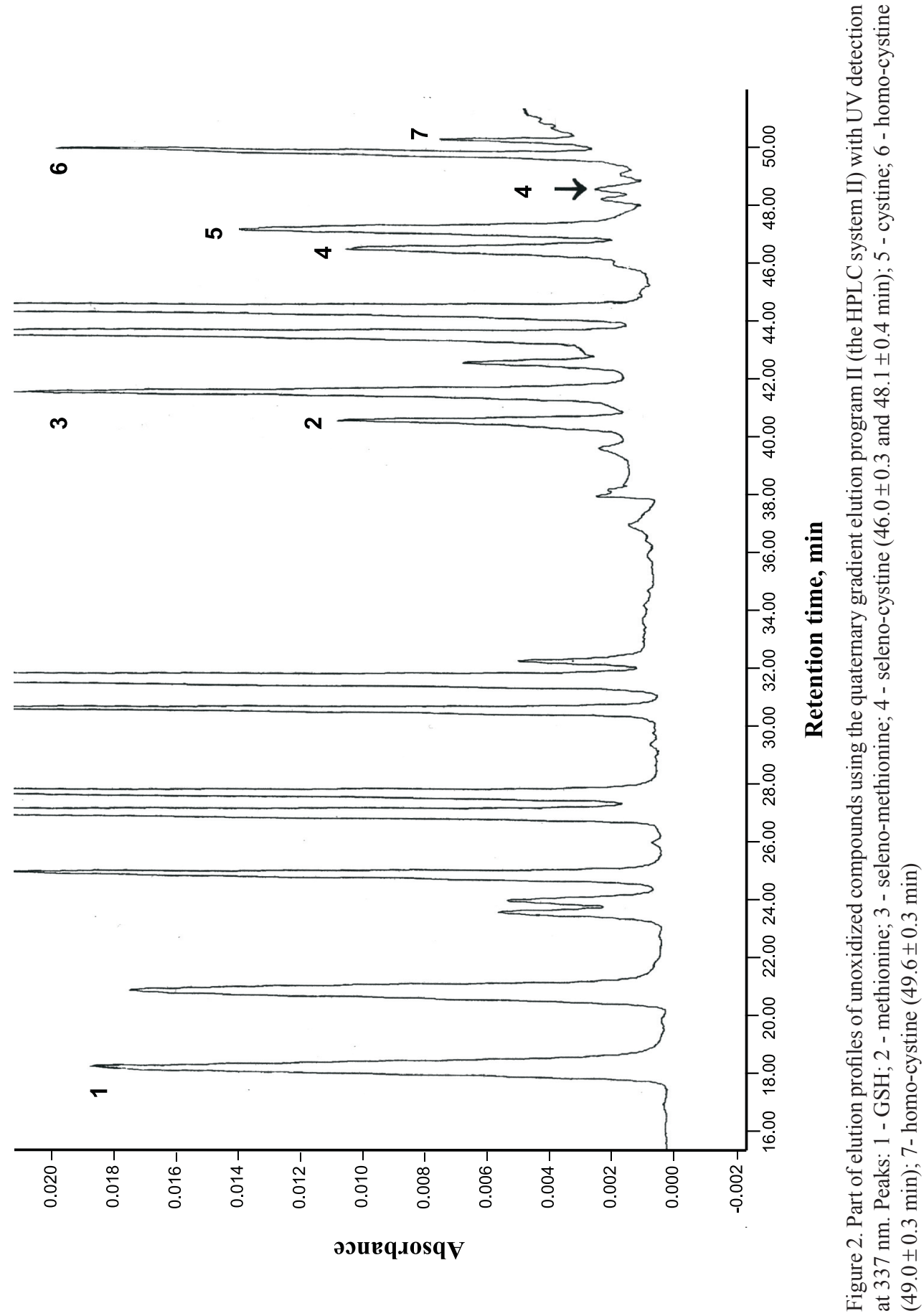
were practically identical for all assayed compounds. As can be seen from previous studies and the data summarized in Table 4, cystine (Czauderna at al., 2002), selenocystine and homo-cystine derivatives gave higher UV responses in comparison with fluorescence (Table 4). Surprisingly, seleno-cystine yields the lowest fluorescent properties, while homo-cystine showed the highest fluorescence responses. The obtained results are sensible since the sulphur atom in the homo-cystine molecule is separated from the amino group by one more carbon atom than in the cystine molecule. Our results indicate that the selenium atom in seleno-cystine most efficiently reduced the quantum emission yield of the fluorescent OPA seleniumproduct. On the other hand, the thiol group of GSH decreased the quantum yield of the fluorescent derivative the least. The accuracy of HPLC system II was also proved by determining the relationships between detecting wavelength $\left(\lambda_{\mathrm{nm}}\right)$ and ratios $\left(\mathrm{R}^{\mathrm{nm}}\right)$ of an area of assayed compounds in biological samples $\left(\mathrm{R}_{\text {sample }}^{\mathrm{nm}}\right)$ and standards $\left(\mathrm{R}_{\text {standard }}^{\mathrm{nm}}\right)$ (for abbreviations see in Table 3 ). As can be seen from the results displayed in Table 4, all of the examined compounds can be determined using longer wavelengths. The absorbance maximum near $337 \mathrm{~nm}$ clearly makes these OPA derivatives almost ideally suited for analysis in various types of biological materials. Further detailed analysis of peak purity revealed that ratios $\left(\mathrm{R}^{\mathrm{nm}}\right)$ of seleno-methionine, seleno-cystine and GSH were nearly 1 in the short UV range (Table 4). However, detailed results indicated that, generally, in the short UV range integrated analytical seleno-methionine and seleno-cystine peaks are less pure than in the longer UV range. In particular, poor purity can be found when monitoring homo-cystine via the second peak in the short UV range (Table 4). Considering the above results, it can be concluded that all analytical peaks can be integrated applying the total peak area method as devoid of substantial co-eluting impurities with peaks absorbing in the longer UV range (300-360 nm). HPLC system II based on UV detection at $337 \mathrm{~nm}$ is seen to be the most accurate and precise.

The sensitivity of HPLC system II was assessed by determining the limit of detection $\left(\mathrm{L}_{\mathrm{D}}\right)$ values for the examined analytes. As expected, all values of $\mathrm{L}_{\mathrm{D}}$ for UV detection at $337 \mathrm{~nm}$ are low. Therefore, this detection mode offers satisfactory sensitivity permitting detection and quantification $\left(\mathrm{L}_{\mathrm{Q}}=3 \cdot \mathrm{L}_{\mathrm{D}}\right)$ of relatively low levels of assayed compounds when compared with original levels of these species in biological materials. The results of GSH, seleno-methionine and methionine (Czauderna et al., 2002) are particularly important (Table 4) because fluorescence detection provides better sensitivity than $\mathrm{UV}$ detection, while worse $\mathrm{L}_{\mathrm{D}}$ for selenocystine, homo-cystine and cystine (Czauderna et al., 2002). Considering the results summarized in Table 4 and HPLC chromatograms (Figure 2), both seleno-cystine and homo-cystine in biological materials should be quantified using the first (larger) peak of OPA derivatives. 
叫
雪

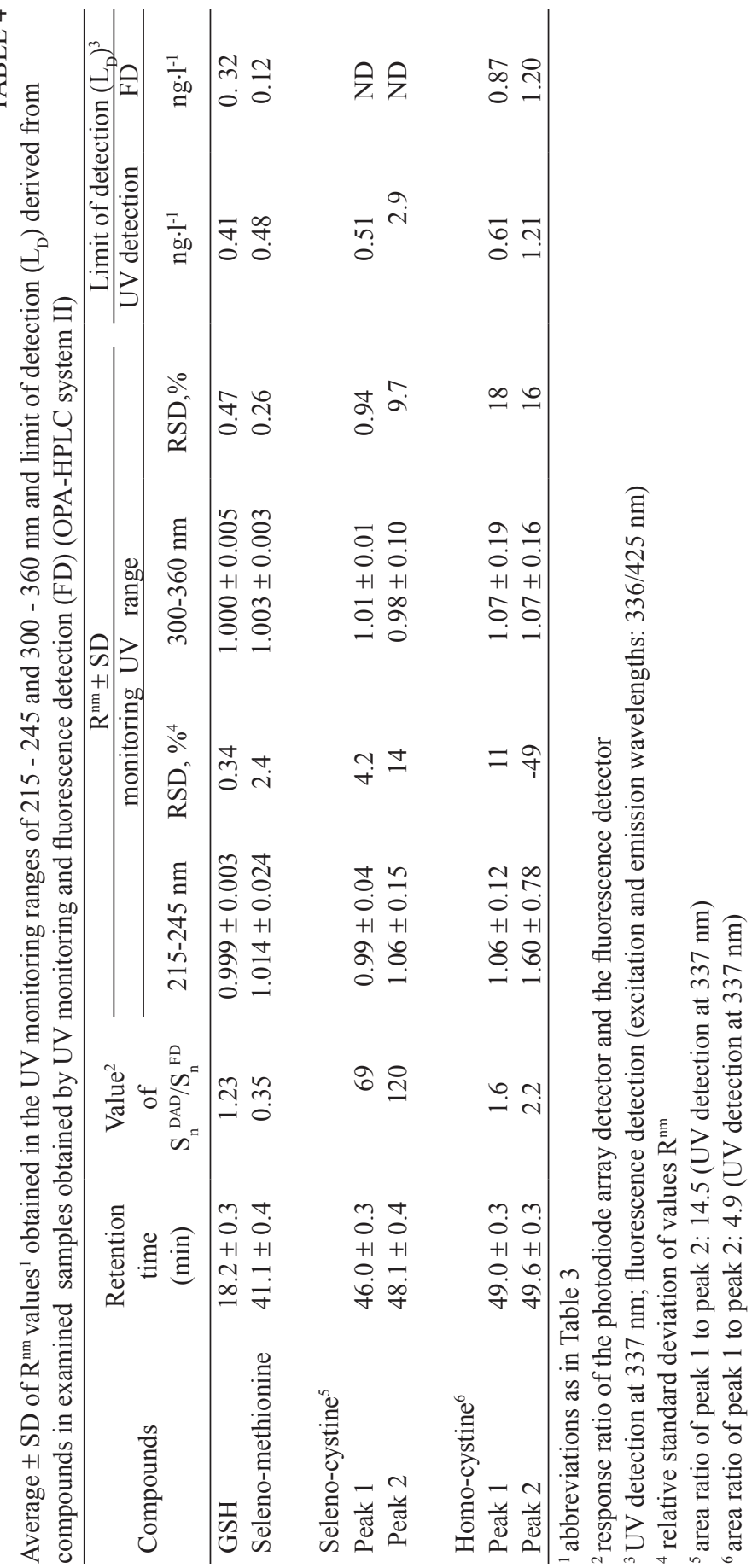




\section{CONCLUSIONS}

The HPLC methods presented are highly accurate, selective and sensitive for simultaneous determination of proline, GSH, and some sulphur and selenium amino acids. Proline, cyst(e)ine, methionine and GSH prior to OPA-HPLC analysis are oxidized using the two improved procedures. Due to the use of gentle oxidation conditions, we always obtained pure products. Next, OPA-derivatives of oxidized compounds were separated using widely available and relatively inexpensive $\mathrm{C}_{18}$ columns and typical UV or fluorescence detectors. Fortunately, all assayed compounds can be monitored using a UV detector only because the limits of detection are low compared with the original content of cyst(e)ine, methionine, proline and GSH in biological samples. The combination of pre-column OPA derivatization and gradient elution program II (HPLC system II) provides quantitative information on concentrations of free GSH, seleno-cystine, homo-cystine, methionine and selenomethionine in the presence of other amino acids (Czauderna et al., 2002). The free cysteine concentration can be calculated by subtraction of the results based on the method using OPA derivatization (HPLC system II) from the results based on the method including two oxidation procedures followed by OPA derivatization (HPLC system I). The presented HPLC methods with selective UV detection, based on simple and rapid preparation, can be possible alternative methods to other methods with fluorescence detection. Our HPLC procedures should find application especially in routine analysis of GSH, proline, and sulphur and selenium amino acids in the presence of other amino acids in nutritional and clinical laboratories.

\section{REFERENCES}

Bald E., Głowacki R., 2001. 2-Chloro-1-methylquinolinium tetrafluoroborate as an effecttive and thiol specific UV-tagging reagent for liquid chromatography. J. Liq. Chromatogr. Relat. Techno. 24, 1323-1339

Bald E., Głowacki R., Drzewoski J., 2001. Determination by liquid chromatography of free and total cysteine in human urine in the form of its $S$-quinolinium derivative. J. Chromatogr. A 913, 319-329

Bech-Andersen S., Rudemo M., Mason V.C., 1980. Hydrolysate preparation for amino acid determinations in feed constituens. Z. Tierphysiol. Tierernähr. Futtermittelk. 43, 57-65

Chwatko G., Bald E., 2002. Determination of different species of hormocysteine in human plasma by high-performance liquid chromatography with ultraviolet detection. J. Chromatogr. A 949, $141-151$

Cohen S.A., Michaud D.P., 1998. Highly Accurate, High Sensitivity Amino Acid Analysis with Novel Activated Carbamates as Pre-Column Derivatizing Reagent. Millipore, Waters Chromatography Division, Milford, Massachusetts (USA) 
Czauderna M., Kowalczyk J., 1998. Determination of free amino acids in blood plasma by highperformance liquid chromatography with fluorescence detection. J. Anim. Feed Sci. 7, 453-463

Czauderna M., Kowalczyk J., 1999. Determination of 2,6-diaminopimelic acid in bacteria, ruminal and duodenal digesta using HPLC with fluorescence or UV detection. J. Anim. Feed Sci. 8, 273-288

Czauderna M., Kowalczyk J., Niedźwiedzka K.M., Wąsowska I., 2002. Determination of free and protein primary amino acids in biological materials by high-performance liquid chromatography and photodiode array detection. J. Anim. Feed Sci. 11, 143-167

Kutlan D., Molnar-Perl I., 2001. Characteristics and stability of the OPA/3-mercaptopropionic acid and OPA/N-acetyl-L-cysteine derivatives of amino acids. Chromatographia 53, Suppl., S188-S198

Lewis A.J., Bayley H.S., 1995. Amino acid bioavailability. In: C.B. Ammerman, D.H. Baker, A.J. Lewis (Editors). Bioavailability of Nutrients for Animals. Academic Press, New York, pp. 35-65

Lindroth P., Hamberger A., Sandberg M., 1985. Amino acids. In: A.A. Boulton, G.B. Baker, J.D. Wood (Editors). Neuromethods. The HUMANA Press, Inc., Vol. 3, pp. 97-116

Meyer V.R., 1999. Practical High-Performance Liquid Chromatography. John Wiley and Sons, Chichester (UK), p. 78

Moller S.E., 1993. Quantification of physiological amino acids by gradient ion-exchange highperformance liquid chromatography. J. Chromatogr. 613, 223-230

Molnar-Perl I., 2001. Derivatization and chromatographic behavior of the o-phthaldialdehyde amino acid derivatives obtained with various SH-group-containing additives. J. Chromatogr. A 913, 283-302

Ng L.T., Wong D.Y., Francis T., Anderson G.H., 1991. Ion-exchange chromatography for physiological fluid amino acid analysis. J. Nutr. Biochem. 2, 671-679

Peter A., Torok G., Armstrong D.W., 1998. High-performance liquid chromatographic separation of enantiomers of unusual amino acids on a teicoplanin chiral stationary phase. J. Chromatogr. 793, 238-296

Polak B., Golkiewicz W., 2000. Retention and selectivity of amino acid ester derivatives on (R)-N(3,5-dinitrobenzoyl)-phenylglycine column. J. Liq. Chromatogr. Relat. Techno. 23, 2807-2818

Ravindran V., Bryden W.L., 1999. Amino acid availability in poultry - in vitro and in vivo measurements. Aust. J. Agr. Res. 50, 889-908

Sawar G., Botting H.G., 1993. Evaluation of liquid chromatographic analysis of nutritionally important amino acids in food and physiological samples. J. Chromatogr. 615, 1-22

Williams A.P., 1994. Recent developments in amino acids analysis. In: J.P.F. D’Mello (Editor). Amino Acids in Farm Animal Nutrition. CAB International, Wallingford (UK), pp. 11-36

Żebrowska T., Buraczewski S., 1998. Methods for determination of amino acids bioavailability in pig - Review. Asian-Austr. J. Anim. Sci. 11, 620-633 


\section{STRESZCZENIE}

\section{Oznaczanie niektórych aminokwasów i glutationu wysokosprawną metodą chromatografii cieczowej}

Opisano metody HPLC (I i II) oznaczania cysteiny, seleno-cysteiny, seleno-metioniny, metioniny, homo-cysteiny, glutationu (GSH) i proliny w próbkach biologicznych. Analizowane związki przeprowadzono w pochodne używając $o$-dialdehydu ftalowego (OPA) w obecności etanotiolu. Przed przeprowadzeniem w pochodne, cysteinę, metioninę, GSH utleniano kwasem nadmrówkowym, natomiast prolinę podchlorynem sodowym. Pochodne OPA utlenionych związków rozdzielano wykorzystując kolumę $\mathrm{C}_{18}$ z odwróconą fazą $(4 \mu \mathrm{m}, 250$ x $4.6 \mathrm{~nm}$, Nova Pak, Waters) poprzez binarną elucję gradientową (I metoda HPLC). Pochodne tych związków oznaczano stosując detekcję UV przy dhugości fali $336 \mathrm{~nm}$ oraz detekcję fluorescencyjną (wzbudzanie $\lambda_{\mathrm{ex}}=336 \mathrm{~nm}$, pomiar $\lambda_{\mathrm{em}}=425 \mathrm{~nm}$ ). Stosując detekcję fluorescencyjną otrzymuje się niższe wartości granicy detekcji $\left(\mathrm{L}_{\mathrm{D}}\right)\left(0.3-0.8 \mathrm{ng} \cdot \mathrm{l}^{-1}\right)$ niż wykorzystując monitorowanie UV $\left(0.9-2 \cdot 4 \mathrm{ng} \cdot \mathrm{l}^{-1}\right)$. Czas rozdzielenia wszystkich analitów wynosił ok. 35 min. Oznaczanie pochodnych OPA nieutlenionego GSH, metioniny, seleno-metioniny, cystyny, seleno-cystyny i homo-cystyny, przeprowadzono poprzez poczwórną elucję gradientową (II metoda HPLC) wykorzystując detekcję UV przy $337 \mathrm{~nm}$ oraz detekcję fluorescencyjną $\left(\lambda_{\text {ex }} / \lambda_{\mathrm{em}}=336 / 425\right.$ $\mathrm{nm})$. Stosując detekcję UV otrzymuje się niższe wartości $\mathrm{L}_{\mathrm{D}}$ dla seleno-cystyny i homo-cystyny, natomiast detekcja flurescencyjna zapewnia lepsze granice oznaczalności GSH, seleno-metioniny i metioniny. „Czystość” analitycznych pików ( 100\%) oznaczanych związków oraz precyzja i prostota metody HPLC I i II jest wystarczająca do rutynowego oznaczania badanych związków w próbkach biologicznych. 